\title{
Quality and safety management at bakeries
}

\author{
Valentina Bukhovets ${ }^{*}$, Diana Shkurina, and Tatyana Demina \\ Saratov State Agrarian University named after N.I. Vavilov, 410012, 1, Theatre sq., Saratov, \\ Russian Federation
}

\begin{abstract}
For bakeries, the main task is to produce bread of the best quality. In order to do this, the company must control the batches of incoming raw materials, semi-finished products and finished products. The quality of bread is a set of characteristics that determine the consumer properties of food products and ensure safety for humans. The use of the HACCP system is currently mandatory and is of great importance in the field of food production. JSC "Saratov bakery named after I.K. Struzhkin" is the main supplier of bakery products in Saratov and the Saratov region. In the work, a survey of all stages of the technological process of the production of bakery products of the therapeutic and preventive direction was carried out, quality management systems were analyzed. Control critical points have been identified, a package of documents and a plan for the implementation of the HACCP system at the Saratov Bakery named after I.K. Struzhkin JSC have been prepared.
\end{abstract}

\section{Introduction}

Taking into account the development of the food industry and the economic development of the country as a whole, the state has taken steps to create and operate a product quality management system. The most significant for the Russian economy is the creation and development of the Customs Union, which tends to expand [1]. In these conditions, it became necessary to create a unified system of control and quality management of manufactured products, which allows to implement timely measures to prevent, identify and eliminate deficiencies and errors in production, to bring reliable information about the manufactured product to the consumer. To date, the system based on the use of HACCP principles copes with the task best.

\section{Methods}

The purpose of the study is to develop a HACCP plan for an enterprise producing therapeutic and preventive types of bakery products. The object of the study was JSC "Saratov Bakery named after I.K. Struzhkin". Methods of analysis, synthesis and standardized methods for risk analysis: decision tree method, matrix methods $[2,3,4,5,6]$.

\footnotetext{
*Corresponding author: author@email.org
} 


\section{Results}

JSC "Saratov Bakery named after I.K. Struzhkin" is a large manufacturer of bakery, flour confectionery, cakes and pastries of short-term storage. The design capacity is 50 tons of products per day. Despite the great competition, the bakery continues to hold the main volumes of bakery products sold in the city for different groups of the population and is the main supplier for many commercial enterprises.

Assessing the possibility of implementing the HACCP system for therapeutic and prophylactic products at the bakery, an in-depth analysis of all stages of the bakery production process was carried out in accordance with ISO 2200 "Food Safety Management System" standard and documents were prepared [7,8].

The first stage of the HACCP development process at the enterprise is the issuance of an order on the creation of a working group. The group included a coordinator, a technical secretary, a deputy director for production, a technologist, a chief power engineer, an occupational safety engineer, and a head of a finished product warehouse. The main tasks of the group were the development and implementation of the principles of HACCP, the approval of the HACCP program at JSC "Saratov Bakery named after I.K. Struzhkin".

According to the requirements of the regulatory documentation, a description of therapeutic and preventive products has been prepared. The characteristic of the technology of production of therapeutic and prophylactic bakery products was presented in the form of a block diagram, Figure 1.

Input control of raw materials and materials was carried out for compliance with the indicator provided by the current regulatory and technical documentation, the results of the control are recorded in a journal, the form of which is provided by departmental regulatory and technical documentation.

When developing the HACCP system at JSC "Saratov Bakery named after I.K. Struzhkin", three types of potentially dangerous factors were identified: biological, chemical and physical.

After identifying potentially dangerous factors characteristic of the production of bakery products, the dangerous factors prevailing at each stage of production were indicated, Table 1.

Table 1. Hazardous factors of production.

\begin{tabular}{|c|c|}
\hline $\begin{array}{l}\text { Stage of the } \\
\text { technological } \\
\text { process }\end{array}$ & Hazardous factors \\
\hline $\begin{array}{l}\text { Acceptance } \\
\text { and storage of } \\
\text { raw materials }\end{array}$ & $\begin{array}{l}\text { 1. Birds, rodents, insects and their waste products; } \\
\text { 2. KMAFAnM; } \\
\text { 3. BGKP; } \\
\text { 4. Pathogenic, including Salmonella; } \\
\text { 5. Pesticides; } \\
\text { 6. Toxic elements; } \\
\text { 7. Mycotoxins; } \\
\text { 8. Infection with the causative agent of the "potato disease" of bread (Bacillus } \\
\text { subtilis); } \\
\text { 9. S. Aureus; } \\
\text { 10. Mold; } \\
\text { 1. Contamination and pest infestation of grain stocks (insects, mites); } \\
\text { 12. Metal mixtures; } \\
\text { 13. Non-compliance with sanitary and hygienic requirements by personnel; } \\
\text { 14. Personal belongings. }\end{array}$ \\
\hline
\end{tabular}




\begin{tabular}{|c|c|}
\hline $\begin{array}{l}\text { Preparation } \\
\text { and dosing of } \\
\text { raw materials }\end{array}$ & $\begin{array}{l}\text { 1. Birds, rodents, insects and their waste products; } \\
\text { 2. KMAFAnM; } \\
\text { 3. BGKP; } \\
\text { 4. Pathogenic, including Salmonella; } \\
\text { 5. Infection with the causative agent of the "potato disease" of bread; } \\
\text { 6. Contamination, pest infestation of grain stocks (insects, mites); } \\
\text { 7. S. Aureus; } \\
\text { 8. Mold; } \\
\text { 9. Metal mixtures; } \\
\text { 10. Non-compliance with sanitary and hygienic requirements by personnel; } \\
\text { 11. Personal belongings. }\end{array}$ \\
\hline $\begin{array}{l}\text { Kneading the } \\
\text { dough }\end{array}$ & $\begin{array}{l}\text { 1. Detergent elements, contaminated containers and equipment; } \\
\text { 2. KMAFAnM; } \\
\text { 3. BGKP; } \\
\text { 4. Pathogenic, including salmonella; } \\
\text { 5. Non-compliance with sanitary and hygienic requirements by personnel; } \\
6 \text { Personal belongings. }\end{array}$ \\
\hline $\begin{array}{l}\text { Fermentation } \\
\text { of the dough }\end{array}$ & $\begin{array}{l}\text { 1. Detergent elements, contaminated containers and equipment; } \\
\text { 2. KMAFAnM; } \\
\text { 3. BGKP; } \\
\text { 4. Pathogenic, including salmonella; } \\
\text { 5. Non-compliance with sanitary and hygienic requirements by personnel; } \\
6 \text { Personal belongings. }\end{array}$ \\
\hline $\begin{array}{l}\text { Cutting the } \\
\text { dough } \\
\text { (dividing into } \\
\text { pieces, } \\
\text { rounding) }\end{array}$ & $\begin{array}{l}\text { 1. Detergent elements, contaminated containers and equipment; } \\
\text { 2. KMAFAnM; } \\
\text { 3. BGKP; } \\
\text { 4. Pathogenic, including salmonella; } \\
\text { 5. Non-compliance with sanitary and hygienic requirements by personnel. }\end{array}$ \\
\hline $\begin{array}{l}\text { Proofing of test } \\
\text { blanks }\end{array}$ & $\begin{array}{l}\text { 1. Detergent elements, contaminated containers and equipment; } \\
\text { 2. KMAFAnM; } \\
\text { 3. BGKP; } \\
\text { 4. Pathogenic, including salmonella; } \\
\text { 5. Non-compliance with sanitary and hygienic requirements by personnel; } \\
\text { 6. Secondary fat oxidation products. }\end{array}$ \\
\hline $\begin{array}{l}\text { Bakery } \\
\text { products }\end{array}$ & $\begin{array}{l}\text { 1. Detergent elements, contaminated containers and equipment; } \\
\text { 2. Non-compliance with sanitary and hygienic requirements by personnel; } \\
\text { 3. Products of secondary oxidation of fat. }\end{array}$ \\
\hline Cooling & $\begin{array}{l}\text { 1. Birds, rodents, insects and their waste products; } \\
\text { 2. Detergent elements, contaminated containers and equipment; } \\
\text { 3. KMAFAnM; } \\
\text { 4. BGKP; } \\
\text { 5 Pathogenic, including salmonella; } \\
\text { 6. Non-compliance with sanitary and hygienic requirements by personnel. }\end{array}$ \\
\hline Packaging & $\begin{array}{l}\text { 1. Birds, rodents, insects and their waste products; } \\
\text { 2. Non-compliance with sanitary and hygienic requirements by personnel. }\end{array}$ \\
\hline Stacking & $\begin{array}{l}\text { 1. Birds, rodents, insects and their waste products; } \\
\text { 2. Non-compliance with sanitary and hygienic requirements by personnel. }\end{array}$ \\
\hline Storage & $\begin{array}{l}\text { 1. Birds, rodents, insects and their waste products; } \\
\text { 2. KMAFAnM; } \\
\text { 3. BGKP; } \\
\text { 4. Pathogenic, including salmonella; } \\
\text { 5. Non-compliance with sanitary and hygienic requirements by personnel; } \\
\text { 6. Personal belongings. }\end{array}$ \\
\hline Transportation & $\begin{array}{l}\text { 1. Birds, rodents, insects and their waste products; } \\
\text { 2. Non-compliance with sanitary and hygienic requirements by personnel; } \\
\text { 3. Personal belongings. }\end{array}$ \\
\hline
\end{tabular}




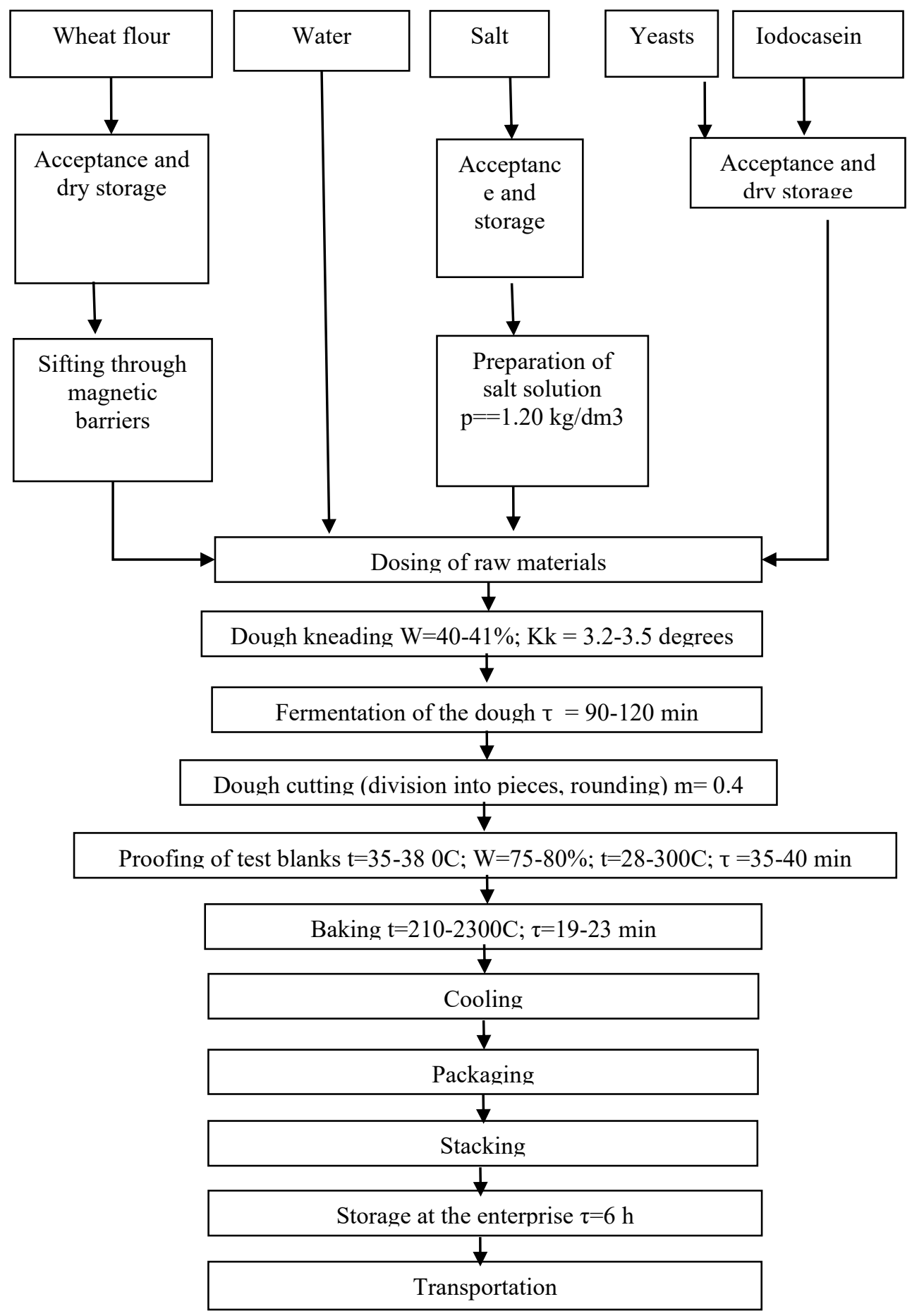

Fig. 1. Technological flowchart for the production of a therapeutic and prophylactic product with iodocasein. 
Input control of raw materials and materials was carried out for compliance with the indicators provided for by the current regulatory and technical documentation, the results of the control are recorded in a journal, the form of which is provided for by departmental regulatory and technical documentation $[9,10]$.

\section{Discussion}

Based on the results of the analysis from the list of potential factors, a list of factors was compiled for which the risk exceeds the permissible level and actions within the HACCP system are aimed at their transformation (Table 2).

Table 2. Considered dangerous factors.

\begin{tabular}{|l|c|}
\hline \multicolumn{1}{|c|}{ Name of the hazardous factor } & Note \\
\hline KMAFAnM & TR CU 021/2011 \\
\hline BGKP & TR CU 021/2011 \\
\hline Pathogenic including salmonella & SanPiN 2.3.2.1078-01 \\
\hline Pesticides & TR CU 021/2011 \\
\hline Toxic elements & TR CU 021/2011 \\
\hline Infection of b.r. Bacillus subtilis & TR CU 021/2011 \\
\hline Metal mixtures & - \\
\hline $\begin{array}{l}\text { Detergent elements, contaminated containers and } \\
\text { equipment }\end{array}$ & - \\
\hline Mould & TR CU 021/2011 \\
\hline S. Aureus & TR CU 021/2011 \\
\hline
\end{tabular}

A list of preventive actions for each dangerous factor at all stages of the technological process has been compiled and developed for JSC "Saratov Bakery named after I.K. Struzhkin", Table 3 [11].

Table 3. A list of preventive actions at work.

\begin{tabular}{|c|c|c|}
\hline Name of the operation & Hazardous factors & Preventive actions \\
\hline Input control of raw materials & $\begin{array}{l}\text { B: KMAFAnM, BGCP, } \\
\text { Pathogenic, including } \\
\text { salmonella, mold. } \\
\text { X: Toxic elements, pesticides, } \\
\text { mycotoxins. }\end{array}$ & $\begin{array}{l}\text { Control of the accompanying } \\
\text { documentation. } \\
\text { Control of the content of the } \\
\text { mass fraction of moisture. } \\
\text { In case of unsatisfactory results, } \\
\text { rejection and return of raw } \\
\text { materials to the supplier. }\end{array}$ \\
\hline Storage & B: Mold & $\begin{array}{l}\text { Control of air temperature and } \\
\text { humidity. }\end{array}$ \\
\hline \multirow[t]{2}{*}{ Dosing of raw materials } & $\begin{array}{l}\text { F: Stones, sand, wood, birds, } \\
\text { rodents, insects and their waste } \\
\text { products }\end{array}$ & $\begin{array}{l}\text { Technical inspection of } \\
\text { equipment, removal of foreign } \\
\text { objects, replacement of } \\
\text { inoperable sieves. }\end{array}$ \\
\hline & B: Mold & $\begin{array}{l}\text { Control of air temperature and } \\
\text { humidity. }\end{array}$ \\
\hline \multirow{2}{*}{ Kneading the dough } & F: Foreign objects & $\begin{array}{l}\text { Technical inspection of the } \\
\text { equipment. }\end{array}$ \\
\hline & $\begin{array}{l}\text { F: Rodents, insects and their } \\
\text { waste products }\end{array}$ & Disinfection, disinsection. \\
\hline Fermentation of the dough & F: Foreign objects & $\begin{array}{l}\text { The presence of covers for the } \\
\text { dezh. }\end{array}$ \\
\hline Cutting the dough & F: Foreign objects & Inspection of equipment every \\
\hline
\end{tabular}




\begin{tabular}{|l|l|l|}
\hline & & shift, hygiene by staff. \\
\hline & $\begin{array}{l}\text { F: Rodents, insects and their } \\
\text { waste products }\end{array}$ & Disinfection, disinsection. \\
\hline Packaging, labeling & F: Paper, packaging material & $\begin{array}{l}\text { Control of air temperature and } \\
\text { humidity. }\end{array}$ \\
\hline
\end{tabular}

According to the data obtained, it was found that each technological operation of the production of bakery products needs strict control, compliance with technological parameters and sanitary and hygienic requirements, Table 4.

Table 4. Critical control points for the production of therapeutic and prophylactic products.

\begin{tabular}{|c|c|c|c|}
\hline $\begin{array}{l}\text { Name of the } \\
\text { technological } \\
\text { operation }\end{array}$ & $\begin{array}{l}\text { Number of the } \\
\text { combined } \\
\text { CCT }\end{array}$ & $\begin{array}{l}\text { The number of } \\
\text { the original CCT }\end{array}$ & $\begin{array}{l}\text { The considered } \\
\text { dangerous factor }\end{array}$ \\
\hline \multirow{10}{*}{$\begin{array}{l}\text { 1. Acceptance and storage } \\
\text { of raw materials }\end{array}$} & \multirow{10}{*}{ CCT 1} & CCT 1 & №1 - KMAFAnM \\
\hline & & CCT 2 & №2 - BGKP \\
\hline & & CCT 3 & №3 - Salmonella \\
\hline & & CCT 4 & №4 - Pesticides \\
\hline & & CCT 5 & №5 - Toxic elements \\
\hline & & CCT 6 & №6 - Bacillus subtilis \\
\hline & & $\mathrm{CCT} 7$ & $\begin{array}{l}\text { №7 - Metal impurities, } \\
\text { impurities }\end{array}$ \\
\hline & & CCT 8 & $\begin{array}{l}\text { №8 - Contaminated } \\
\text { containers and equipment. }\end{array}$ \\
\hline & & CCT 9 & №9 - Mould \\
\hline & & CCT 10 & №10 - S.Aureus \\
\hline \multirow{7}{*}{$\begin{array}{l}\text { 2. Preparation and dosing } \\
\text { of raw materials }\end{array}$} & \multirow{7}{*}{ CCT 2} & CCT 11 & №1 - KMAFAnM \\
\hline & & CCT 12 & №2 - BGKP \\
\hline & & CCT 13 & №3 - Salmonella \\
\hline & & CCT 14 & №6 - Bacillus subtilis \\
\hline & & CCT 15 & $\begin{array}{l}\text { №8 - Contaminated } \\
\text { containers and equipment. }\end{array}$ \\
\hline & & CCT 16 & №9 - Mould \\
\hline & & CCT 17 & №10 - S.Aureus \\
\hline \multirow{3}{*}{ 3. Kneading the dough } & \multirow{3}{*}{ CCT 3} & CCT 18 & №6 - Bacillus subtilis \\
\hline & & CCT 19 & $\begin{array}{l}\text { №8 - Contaminated } \\
\text { containers and equipment. }\end{array}$ \\
\hline & & CCT 20 & №9 - S.Aureus \\
\hline \multirow{2}{*}{$\begin{array}{l}\text { 4. Fermentation of the } \\
\text { dough }\end{array}$} & \multirow[b]{2}{*}{$\mathrm{CCT} 4$} & CCT 21 & №6 - Bacillus subtilis \\
\hline & & ССТ 22 & $\begin{array}{l}\text { №8 - Contaminated } \\
\text { containers and equipment. }\end{array}$ \\
\hline \multirow{3}{*}{$\begin{array}{l}\text { 5. Cutting the dough } \\
\text { (dividing into pieces, } \\
\text { rounding) }\end{array}$} & \multirow{3}{*}{ CCT 5} & CCT 23 & №1 - KMAFAnM \\
\hline & & CCT 24 & №2 - BGKP \\
\hline & & CCT 25 & $\begin{array}{l}\text { №8 - Contaminated } \\
\text { containers and equipment. }\end{array}$ \\
\hline 6. Proofing of test pieces & CCT 6 & CCT 26 & $\begin{array}{l}\text { №8 - Contaminated } \\
\text { containers and equipment. }\end{array}$ \\
\hline \multirow{4}{*}{ 7. Cooling } & \multirow{2}{*}{ ССТ 7} & CCT 27 & №1 - KMAFAnM \\
\hline & & CCT 28 & №2 - BGKP \\
\hline & & CCT 29 & №3 - Salmonella \\
\hline & & CCT 30 & $\begin{array}{l}\text { №8 - Contaminated } \\
\text { containers and equipment. }\end{array}$ \\
\hline \multirow{2}{*}{ 8. Storage } & \multirow{2}{*}{ CCT 8} & CCT 31 & №1 - KMAFAnM \\
\hline & & CCT 32 & №2 - BGKP \\
\hline
\end{tabular}




\begin{tabular}{|l|l|l|l|}
\hline \multirow{2}{*}{} & CCT 33 & №3 - Salmonella \\
\cline { 3 - 4 } & CCT 34 & №6 - Bacillus subtilis \\
\cline { 3 - 4 } & CCT 35 & №9 - Mould \\
\cline { 3 - 4 } & CCT 36 & №10 - S.Aureus \\
\hline
\end{tabular}

Using the decision tree, 8 critical control points were obtained, according to which monitoring systems and corrective actions were developed, taking into account the nature of the controlled risk, the production process, the capabilities of the enterprise, the qualifications of personnel. The method of monitoring, the frequency of monitoring, the responsibility for monitoring, and the requirements for keeping records during monitoring were determined. The results obtained are presented in Table 5.

Table 5. Corrections and corrective actions for CCT.

\begin{tabular}{|c|c|c|c|c|}
\hline $\begin{array}{c}\text { CCT No. and the } \\
\text { name of the } \\
\text { operation }\end{array}$ & $\begin{array}{l}\text { Controlled } \\
\text { parameter }\end{array}$ & $\begin{array}{c}\text { Corrective action } \\
\text { and correction } \\
\text { methods }\end{array}$ & $\begin{array}{c}\text { Responsibl } \\
\text { e }\end{array}$ & $\begin{array}{l}\text { Registration } \\
\text { form }\end{array}$ \\
\hline $\begin{array}{l}\text { 1. Acceptance and } \\
\text { storage of raw } \\
\text { materials }\end{array}$ & $\begin{array}{l}\text { Accompanying } \\
\text { documentation; } \\
\text { shelf life }\end{array}$ & $\begin{array}{l}\text { Return of raw } \\
\text { materials to the } \\
\text { supplier, informing } \\
\text { management of non- } \\
\text { compliance }\end{array}$ & Storekeeper & $\begin{array}{l}\text { Acceptance } \\
\text { control log, } \\
\text { return certificate, } \\
\text { service note }\end{array}$ \\
\hline $\begin{array}{l}\text { 2. Preparation and } \\
\text { dosing of raw } \\
\text { materials }\end{array}$ & $\begin{array}{l}\text { Foreign objects } \\
\text { in raw materials }\end{array}$ & $\begin{array}{l}\text { Technical inspection } \\
\text { for foreign objects, } \\
\text { repair in case of } \\
\text { equipment failure }\end{array}$ & Plot Master & $\begin{array}{l}\text { Journal of } \\
\text { technological } \\
\text { control, memo }\end{array}$ \\
\hline $\begin{array}{l}\text { 3. Kneading the } \\
\text { dough }\end{array}$ & Foreign objects & $\begin{array}{l}\text { Technical inspection } \\
\text { for foreign objects, } \\
\text { repair in case of } \\
\text { equipment failure. } \\
\text { Informing the } \\
\text { manager. }\end{array}$ & Plot Master & $\begin{array}{l}\text { Journal of } \\
\text { technological } \\
\text { control, memo }\end{array}$ \\
\hline $\begin{array}{l}\text { 4. Fermentation of } \\
\text { the dough }\end{array}$ & $\begin{array}{l}\text { The acidity of } \\
\text { the test }\end{array}$ & $\begin{array}{l}\text { Informing the } \\
\text { supervisor to make a } \\
\text { decision on the further } \\
\text { use of the test }\end{array}$ & Plot Master & $\begin{array}{l}\text { Journal of } \\
\text { technological } \\
\text { control, memo }\end{array}$ \\
\hline 5. Cutting the dough & $\begin{array}{l}\text { Temperature, } \\
\text { humidity and } \\
\text { acidity }\end{array}$ & $\begin{array}{l}\text { Informing the } \\
\text { supervisor to make a } \\
\text { decision on the further } \\
\text { use of the test }\end{array}$ & Plot Master & $\begin{array}{l}\text { Journal of } \\
\text { technological } \\
\text { control, journal } \\
\text { of temperature } \\
\text { control, memo } \\
\end{array}$ \\
\hline $\begin{array}{l}\text { 6. Proofing of test } \\
\text { pieces }\end{array}$ & $\begin{array}{l}\text { Temperature } \\
\text { and humidity }\end{array}$ & $\begin{array}{l}\text { Temperature and } \\
\text { humidity control. } \\
\text { Informing the } \\
\text { technologist about the } \\
\text { violation }\end{array}$ & Plot Master & $\begin{array}{l}\text { Temperature } \\
\text { control log, } \\
\text { memo }\end{array}$ \\
\hline 7. Cooling & Temperature & $\begin{array}{l}\text { The temperature in the } \\
\text { bread storage. } \\
\text { Informing the } \\
\text { technologist about the } \\
\text { violation of the storage } \\
\text { duration }\end{array}$ & Plot Master & $\begin{array}{l}\text { Temperature } \\
\text { control log, } \\
\text { memo }\end{array}$ \\
\hline
\end{tabular}




\begin{tabular}{|l|l|l|l|l|}
\hline 8. Storage & Temperature & $\begin{array}{l}\text { Temperature } \\
\text { regulation. Informing } \\
\text { the technologist about } \\
\text { the violation of the } \\
\text { storage duration }\end{array}$ & Storekeeper & $\begin{array}{l}\text { Temperature } \\
\text { control log, } \\
\text { memo }\end{array}$ \\
\hline
\end{tabular}

As a result of the work done to provide structural units with the necessary and reliable information to perform their functions and measures to ensure safety in the production process, a systematic list of HACCP system documentation was compiled, Table 6.

Table 6. List of developed HACCP system documentation.

\begin{tabular}{|c|c|c|c|c|}
\hline $\begin{array}{l}\text { HACCP } \\
\text { System } \\
\text { Document } \\
\text { ation } \\
\text { Requirem } \\
\text { ents } \\
\end{array}$ & Content & $\begin{array}{l}\text { Name of the } \\
\text { document }\end{array}$ & $\begin{array}{l}\text { Storage } \\
\text { location }\end{array}$ & Responsible \\
\hline $\begin{array}{l}\text { 1. The } \\
\text { structure of } \\
\text { the } \\
\text { company }\end{array}$ & $\begin{array}{l}\text { The structure of } \\
\text { the enterprise } \\
\text { JSC "Saratov } \\
\text { bakery named } \\
\text { after I.K. } \\
\text { Struzhkin" }\end{array}$ & $\begin{array}{l}\text { The organizational } \\
\text { structure of the } \\
\text { enterprise, the } \\
\text { Policy in the field of } \\
\text { product safety, the } \\
\text { Order on the } \\
\text { creation of the } \\
\text { HACCP group }\end{array}$ & $\begin{array}{l}\text { Administrati } \\
\text { ve } \\
\text { department }\end{array}$ & Executive Director \\
\hline \multirow{6}{*}{$\begin{array}{l}2 . \\
\text { Documents } \\
\text { on } \\
\text { supporting } \\
\text { actions }\end{array}$} & $\begin{array}{l}\text { Input control of } \\
\text { raw materials } \\
\text { and materials }\end{array}$ & $\begin{array}{l}\text { The plan of } \\
\text { production control } \\
\text { of the enterprise }\end{array}$ & $\begin{array}{l}\text { Department } \\
\text { of the Chief } \\
\text { Technologist }\end{array}$ & Technologist \\
\hline & $\begin{array}{l}\text { The order to } \\
\text { work with } \\
\text { nonconforming } \\
\text { products }\end{array}$ & $\begin{array}{l}\text { Management of } \\
\text { nonconforming } \\
\text { products }\end{array}$ & $\begin{array}{l}\text { Department } \\
\text { of the Chief } \\
\text { Technologist }\end{array}$ & Technologist \\
\hline & $\begin{array}{l}\text { Equipment } \\
\text { maintenance }\end{array}$ & $\begin{array}{l}\text { Equipment } \\
\text { maintenance } \\
\text { schedule }\end{array}$ & $\begin{array}{l}\text { Department } \\
\text { of the Chief } \\
\text { Technologist }\end{array}$ & Technologist \\
\hline & $\begin{array}{l}\text { Cleaning of } \\
\text { premises }\end{array}$ & $\begin{array}{l}\text { Cleaning schedule } \\
\text { Instructions on the } \\
\text { cleaning procedure }\end{array}$ & $\begin{array}{l}\text { Department } \\
\text { of the Chief } \\
\text { Technologist }\end{array}$ & Technologist \\
\hline & $\begin{array}{l}\text { Cleaning of the } \\
\text { territory of the } \\
\text { enterprise, } \\
\text { garbage } \\
\text { collection }\end{array}$ & $\begin{array}{l}\text { Schedule of sanitary } \\
\text { cleaning of the } \\
\text { territory } \\
\text { Garbage collection } \\
\text { agreement }\end{array}$ & $\begin{array}{l}\text { Department } \\
\text { of the Chief } \\
\text { Technologist } \\
\text { Department } \\
\text { of the Chief } \\
\text { Technologist }\end{array}$ & Head of Production \\
\hline & $\begin{array}{l}\text { Мойка } \\
\text { инвентаря и } \\
\text { дезинфекция } \\
\text { технологическ } \\
\text { ого } \\
\text { оборудования }\end{array}$ & $\begin{array}{l}\text { Schedule of } \\
\text { washing and } \\
\text { disinfection of } \\
\text { inventory and } \\
\text { technological } \\
\text { equipment } \\
\text { Instructions for } \\
\text { washing and } \\
\text { sanitary-hygienic } \\
\text { treatment of } \\
\text { inventory and }\end{array}$ & $\begin{array}{l}\text { Department } \\
\text { of the Chief } \\
\text { Technologist }\end{array}$ & Head of Production \\
\hline
\end{tabular}




\begin{tabular}{|c|c|c|c|c|}
\hline & & \multicolumn{3}{|l|}{ equipment } \\
\hline & $\begin{array}{l}\text { Rodent and } \\
\text { insect control }\end{array}$ & $\begin{array}{l}\text { Journal of the } \\
\text { sanitary condition } \\
\text { of the enterprise } \\
\text { Instructions for pest } \\
\text { control } \\
\text { Contract for the } \\
\text { provision of pest } \\
\text { control services }\end{array}$ & $\begin{array}{l}\text { Department } \\
\text { of the Chief } \\
\text { Technologist }\end{array}$ & Head of Production \\
\hline & $\begin{array}{l}\text { Compliance } \\
\text { with the rules of } \\
\text { personal } \\
\text { hygiene }\end{array}$ & $\begin{array}{l}\text { Instructions for } \\
\text { personal hygiene } \\
\text { Instructional } \\
\text { Magazine }\end{array}$ & $\begin{array}{l}\text { Department } \\
\text { of the Chief } \\
\text { Technologist }\end{array}$ & Head of Production \\
\hline $\begin{array}{l}\text { 3. Product } \\
\text { Information }\end{array}$ & $\begin{array}{l}\text { Product safety } \\
\text { requirements } \\
\text { Names of raw } \\
\text { materials and } \\
\text { packaging } \\
\text { materials, } \\
\text { documents } \\
\text { confirming } \\
\text { safety }\end{array}$ & $\begin{array}{l}\text { List of raw } \\
\text { materials and } \\
\text { packaging materials } \\
\text { used }\end{array}$ & $\begin{array}{l}\text { Department } \\
\text { of the Chief } \\
\text { Technologist }\end{array}$ & Technologist \\
\hline $\begin{array}{l}4 . \\
\text { Production } \\
\text { Information }\end{array}$ & $\begin{array}{l}\text { Description of } \\
\text { technological } \\
\text { production } \\
\text { Location of } \\
\text { production sites }\end{array}$ & $\begin{array}{l}\text { Flowchart of the } \\
\text { technological } \\
\text { process } \\
\text { Enterprise plan }\end{array}$ & $\begin{array}{l}\text { Department } \\
\text { of the Chief } \\
\text { Technologist }\end{array}$ & Technologist \\
\hline $\begin{array}{l}5 . \\
\text { Documents } \\
\text { on } \\
\text { dangerous } \\
\text { factors and } \\
\text { risks }\end{array}$ & $\begin{array}{l}\text { Identification of } \\
\text { potential } \\
\text { hazards, risk } \\
\text { identification } \\
\text { and selection of } \\
\text { considered } \\
\text { hazards }\end{array}$ & $\begin{array}{l}\text { List of potentially } \\
\text { dangerous factors; } \\
\text { Risk analysis and } \\
\text { consideration of } \\
\text { dangerous factors }\end{array}$ & $\begin{array}{l}\text { Department } \\
\text { of the Chief } \\
\text { Technologist }\end{array}$ & Technologist \\
\hline $\begin{array}{l}6 . \\
\text { Documents } \\
\text { with the } \\
\text { definition of } \\
\text { CCT } \\
\end{array}$ & $\begin{array}{l}\text { Methods for } \\
\text { determining } \\
\text { CCT }\end{array}$ & $\begin{array}{l}\text { Results of the } \\
\text { analysis using the } \\
\text { "Decision Tree" } \\
\text { algorithm }\end{array}$ & $\begin{array}{l}\text { Department } \\
\text { of the Chief } \\
\text { Technologist }\end{array}$ & Technologist \\
\hline $\begin{array}{l}7 . \\
\text { Documents } \\
\text { defining } \\
\text { critical } \\
\text { limits, } \\
\text { monitoring } \\
\text { systems and } \\
\text { corrective } \\
\text { actions }\end{array}$ & $\begin{array}{l}\text { Establishment } \\
\text { of control } \\
\text { objects with } \\
\text { indication of } \\
\text { technological } \\
\text { process } \\
\text { operations }\end{array}$ & $\begin{array}{l}\text { HACCP } \\
\text { Worksheets }\end{array}$ & $\begin{array}{l}\text { Department } \\
\text { of the Chief } \\
\text { Technologist }\end{array}$ & Technologist \\
\hline $\begin{array}{l}8 . \\
\text { Accounting } \\
\text { documentati } \\
\text { on }\end{array}$ & $\begin{array}{l}\text { Reflection of } \\
\text { the functioning } \\
\text { of the HACCP } \\
\text { system } \\
\text { according to } \\
\text { monitoring data, } \\
\text { corrective } \\
\text { actions, internal } \\
\text { audit reports }\end{array}$ & $\begin{array}{l}\text { Control logs; } \\
\text { Internal audit } \\
\text { checklists }\end{array}$ & $\begin{array}{l}\text { Department } \\
\text { of the Chief } \\
\text { Technologist }\end{array}$ & Head of Production \\
\hline
\end{tabular}




\section{Conclusion}

Thus, based on the analysis of the production of therapeutic and prophylactic bakery products, the main elements of the quality management system, the HACCP plan have been developed, control critical points have been identified, corrective actions have been established. Documentation and a report system have been created at the bakery enterprise, which can be used to ensure guaranteed production of high-quality and safe products.

\section{References}

1. T. Meyes, S. Mortimor, Effective implementation of HACCP: Learning from the experience of others textbook St. Petersburg, Profession (2008)

2. L. Knowler, J. Howell, B. Gold, E. Coleman, O. Mone, V. Knowler, Statistical methods of product quality control Moscow (Publishing House of Standards, 2016)

3. G. Surak, A. Quality Progress, John Recipe for Safe Food: ISO 22000 and HACCP, 2 (2007)

4. D. Worsfold, C. J. Griffith, Widening HACCP implementation in the catering industry (2021)

5. D.A. Shkurina, V.A Bukhovets, Food technologies of the future: innovations in the production and processing of agricultural products, Mandatory preliminary measures in the HACCP system (2021)

6. V.A. Bukhovets, D.V. Efimova, L.V. Davydova, Technique and technology of food production, Development of technology for the production of bakery products of increased nutritional value Technology and technology of food production, 2 (2019)

7. E. I. Ponomarev, S. I. Lukina, N. N. Alekhina, T. N. Malutina, O. N. Voropayeva, Workshop on Industry Technology (2017)

8. Rye sowing areas in Russia, Results of 2019 (2019)

9. N. N. Alekhina, E. I. Ponomareva, H. Y. Botasheva, N. V. Oleynikov, Materials of the IX All-Russian Scientific and Practical Conference of Scientists of Students, postgraduate, Expansion of raw material base for food production Technologies and equipment of chemical, biotechnology and food industry (2016)

10. N.A. Shyurova, A.A. Tsarenko, I.V. Schmidt, M.E. Rubanova, O.S. Bashinskaya, L.I. Chekmareva, G.N. Popov, International Journal of Engineering and Technology (UAE), Aspects of development of rural territories in the Russian Federation, 38, 4 (2018)

11. N.A. Shyurova, A.G. Subbotin, V.I. Zhuzhukin, V.B. Narushev, N.V. Stepanova, O.S. Bashinskaya, Agrarian Scientific Journal. Evaluation of winter wheat varieties and lines for adaptability to the conditions of the Lower Volga region, 7 (2020) 